\title{
Prevalence, antimicrobial susceptibility and virulotyping of Listeria species and Listeria monocytogenes isolated from open-air fish markets
}

Hossein Jamali ${ }^{1 *}$, Mohammadjavad Paydar ${ }^{2}$, Salmah Ismail ${ }^{1}$, Chung Yeng Looi ${ }^{2}$, Won Fen Wong ${ }^{3}$, Behrad Radmehr ${ }^{4}$ and Atefeh Abedini ${ }^{5}$

\begin{abstract}
Background: The aim of this study was to investigate the prevalence and characterization of Listeria species and Listeria monocytogenes isolated from raw fish and open-air fish market environments. Eight hundred and sixty two samples including raw fish and fish market environments (samples from workers' hands, workers' knives, containers and work surface) were collected from the open-air fish markets in the Northern region of Iran.

Results: Listeria spp. was isolated from 104/488 (21.3 \%) raw fish and 29/374 (7.8 \%) of samples from open-air fish market environment. The isolates of Listeria spp. included L. innocua (35.3\%), L. monocytogenes (32.3\%), L. seeligeri (18\%), and L. ivanovii (14.3\%). Of the 43 L. monocytogenes isolates, 31 (72.1\%), 10 (23.3\%) and 2 (4.7\%) belonged to serovars $1 / 2 \mathrm{a}, 4 \mathrm{~b}$, and $1 / 2 \mathrm{~b}$, respectively. The in/A, in/B, in/C, inlJ, actA, hlyA, iap, plcA, and prfA virulence-associated genes were detected in almost all of the $L$. monocytogenes isolates. The Listeria spp. isolates showed high resistance against tetracycline (23.3\%), penicillin G, and cephalothin (each $16.5 \%$ ). Besides, we observed significant resistance level to tetracycline (27.9\%), ampicillin (20.9\%), cephalothin, penicillin G, and streptomycin (each $16.3 \%$ ) in the $L$. monocytogenes isolates. All of the isolates were susceptible to cefotaxime, gentamicin, kanamycin, and pefloxacin. We found that tetM (25.6\%), tetA (23.3\%), ampC (14\%), and penA (11.6\%) were the most prevalent antibiotic resistance genes in the $L$. monocytogenes isolates.
\end{abstract}

Conclusions: Recovery of potentially pathogenic L. monocytogenes from raw fish and environment of open-air fish market samples in this study is a convincing evidence for the zoonotic potential of listeriosis.

Keywords: Listeria, Seafood, Virulence genes, Serotyping, Antibiotic resistance, Resistance gene

\section{Background}

The genus Listeria includes facultatively anaerobic Gram-positive bacteria. L. ivanovii and L. monocytogenes from this genus are known as pathogenic species and have shown the ability to cause severe diseases in animals and both humans and animals, respectively. Listeriosis is a foodborne infection with high mortality rates which is caused by L. monocytogenes in humans. The pathogen is ubiquitous and has been isolated from

\footnotetext{
* Correspondence: mordabenilofari@gmail.com

'Biohealth Science Program, Institute of Biological Science, Faculty of

Science, University of Malaya, 50603 Kuala Lumpur, Malaysia

Full list of author information is available at the end of the article
}

animals, different types of foods, and environments worldwide [1-3].

There is a high possibility of L. monocytogenes contamination in the captured fish from contaminated waters and environments. The contamination could also happen during transportation and in the environment of fish markets. Although L. monocytogenes has been isolated from seafood, fish and fishery products, no major listeriosis outbreaks with these products has been reported so far [4]. However, contaminated fish and fish products are considered as the most frequent causes of a number of sporadic listeriosis cases [5].

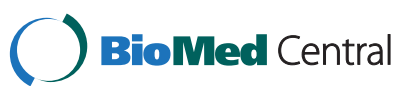

(c) 2015 Jamali et al. This is an Open Access article distributed under the terms of the Creative Commons Attribution License (http://creativecommons.org/licenses/by/4.0), which permits unrestricted use, distribution, and reproduction in any medium, provided the original work is properly credited. The Creative Commons Public Domain Dedication waiver (http:// creativecommons.org/publicdomain/zero/1.0/) applies to the data made available in this article, unless otherwise stated. 
L. monocytogenes can be divided into 13 serovars which serovars $1 / 2 \mathrm{a}, 1 / 2 \mathrm{~b}$ and $4 \mathrm{~b}$ have been mainly reported from foods and human cases of listeriosis [6-8]. The $1 / 2 \mathrm{a}$ is a predominant serovar isolated from food samples [9]. However, serovar $4 \mathrm{~b}$ is known to be the cause of the largest number of human listeriosis outbreaks $[10,11]$.

Different Listeria determinants, which are well known as important factors in pathogenicity of L. monocytogenes, include actin (encoded by act $A$ gene), internalin (encoded by inlA, inlB, inlC, and inlJ genes), invasion associated protein (encoded by iap gene), listeriolysin $\mathrm{O}$ (encoded by $h l y A$ gene), phosphatidylinositol phospholipase $\mathrm{C}$ (encoded by $p l c A$ gene), and virulence regulator (encoded by $\operatorname{prf} A$ gene) [12-15].

Detection of multi-drug resistant pathogenic bacteria in foods is considered as a public health risk worldwide. Excessive application of antibiotics in veterinary medicine may lead to distribution of antibiotic-resistant pathogens in the environment [16]. Recently, multi-drug resistant isolates of $L$. monocytogenes have been detected in animals, different types of foods and human cases of listeriosis [17-20]. Since multi-drug resistant isolates could transmit to humans via contaminated food, proper measures should be taken to prevent their environmental spread. Monitoring of the multi-drug resistant pathogens isolated from food and environment could be useful to identify the patterns of resistance to antibiotics [21].

Mazandaran province, which is located in the North of Iran and near Caspian Sea, fish and fish products are consumed more than other places in Iran. Despite the high consumption of fish and fish products in this area, there is no study on the prevalence and characterization of Listeria spp. and L. monocytogenes from fish and environment of fish markets. Hence, this study was done to investigate the prevalence, serotyping, virulotyping and the resistance patterns of Listeria spp. and L. monocytogenes isolates detected from fish and environment of fish markets in Mazandaran province and the Northern region of Iran.

\section{Methods \\ Sampling}

Between March 2012 and Jun 2014, 488 raw fish samples were purchased at the open-air fish market places in five major cities in Mazandaran Province, North of Iran. The purchased samples included Ctenopharyngodon idella $(n=135)$, Rutilus kutum $(n=124)$, Liza auratus $(n=120)$, and Hypophthalmichthys molitrix $(n=109)$. In addition, 374 environmental and workers swab samples from workers' hands $(n=96)$, workers' knives $(n=96)$, work surface $(n=92)$, and containers $(n=90)$ were collected from the open-air fish markets. All of the samples were transported in ice boxes to the laboratory within $3 \mathrm{~h}$ after sampling. All samples were obtained with the informed consent of the workers and ethics approval for this study was granted by the Islamic Azad University, Iran.

\section{Isolation and detection of Listeria spp.}

Listeria spp. were isolated and detected using ISO112901 method [22]. Briefly, samples were pre-enriched by half Fraser broth (Oxoid, Basingstoke, UK) and enriched by Fraser broth (Oxoid, Basingstoke, UK) for 48 and $24 \mathrm{~h}$ at $37{ }^{\circ} \mathrm{C}$, respectively. Finally, the enriched Fraser broth-culture was streaked onto Palcam agar (Oxoid, Basingstoke, UK) and Oxford agar (Oxoid, Basingstoke, UK) followed by 24 to $48 \mathrm{~h}$ incubation at $37^{\circ} \mathrm{C}$. The presumed colonies were verified by biochemical tests and API Listeria (bioMérieux, Marcy l'Étoile, France). The isolates of Listeria spp. were then further confirmed by PCR [23].

\section{Serotyping of $L$. monocytogenes isolates}

The detected $L$. monocytogenes isolates were serotyped using the commercially prepared Listeria antisera against somatic $(\mathrm{O})$ and flagellar $(\mathrm{H})$ antigens according to the manufacturer (Denka-Seiken Co. Ltd., Tokyo, Japan).

\section{Detection of virulence genes by multiplex-PCR}

Two multiplex-PCR were used for detection of nine virulence-associated genes. Detection of inlA, inlB, inlC, and inlJ genes was performed by a multiplex-PCR using primers and cycling conditions as described by D Liu, ML Lawrence, FW Austin and AJ Ainsworth [13], and $\mathrm{H}$ Jamali and KL Thong [24]. The PCR assay was done as previously described for the $\operatorname{act} A, h l y A$, iap, $p l c A$, and prfA genes in L. monocytogenes isolates [25].

\section{Phenotypic detection of antimicrobial resistance in Listeria spp. isolates}

Antibiotic susceptibility testing was done using the Kirby-Bauer disc diffusion method on Mueller Hinton agar (Oxoid, Basingstoke, UK) supplemented with $5 \%$ defibrinated sheep blood [26]. Ampicillin (30 $\mu \mathrm{g})$, chloramphenicol $(30 \mu \mathrm{g})$, cephalothin $(30 \mu \mathrm{g})$, cefotaxime $(30 \mu \mathrm{g})$, ceftazidime $(30 \mu \mathrm{g})$, cefuroxime $(30 \mu \mathrm{g})$, erythromycin $(15 \mu \mathrm{g})$, florfenicol $(30 \mu \mathrm{g})$, gentamycin $(10 \mu \mathrm{g})$, kanamycin $(30 \mu \mathrm{g})$, pefloxacin $(5 \mu \mathrm{g})$, penicillin $\mathrm{G}(10$ unit), rifampicin $(5 \mu \mathrm{g})$, streptomycin $(30 \mu \mathrm{g})$, tetracycline $(30 \mu \mathrm{g})$, trimethoprim-sulfamethoxazole $(1.25 / 23.75 \mu \mathrm{g})$, and vancomycin $(30 \mu \mathrm{g})$ were applied as antibiotic agents. As CLSI breakpoints for Listeria species only include a few antimicrobial agents such as sulfamethoxazoletrimethoprim, ampicillin, and penicillin; therefore CLSI [26] breakpoints for Enterococcus were used for the other antimicrobial agents as recommended by $M$ Conter, 
D Paludi, E Zanardi, S Ghidini, A Vergara and A Ianieri [27], and Q Li, J Sherwood and C Logue [28].

\section{Antimicrobial resistance genes profiling of $L$. monocytogenes isolates}

The tetracycline resistance genes $(\operatorname{tet} A, \operatorname{tet} B$, tet $C$, tet $L$, tet $M$, and tetS), ampicillin resistance gene (ampC), vancomycin resistance gene (vanA and $\operatorname{vanB}$ ), erythromycin resistance gene $(\mathrm{erm} B)$, florfenicol resistance gene $(f l o R)$, chloramphenicol resistance gene $(\mathrm{cmlA})$, and streptomycin resistance gene ( $\operatorname{str} A$, and $\operatorname{str} B$ ) were detected using PCR as previously described [29-38].

\section{Results and discussion}

Although the people in the Northern region of Iran rely on fish as their primary animal protein source, there is still no study done on the prevalence and characterization of L. monocytogenes in fish and environment of fish markets. The prevalence of Listeria spp. in raw fish and fish markets environments in this study is presented in Table 1. Out of the 862 tested samples, 133 (15.4\%) were contaminated with Listeria spp., out of which 104 (78.2 \%) and $29(21.8 \%)$ were isolated from raw fish and fish market environments, respectively. The Listeria spp. isolates included $L$. monocytogenes ( $n=43,32.3 \%)$, L. innocua $(n=47,35.3 \%)$, L. seeligeri $(n=24,18 \%)$ and L. ivanovii $(n=19,14.3 \%)$. All 43 isolates of L. monocytogenes, identified by biochemical tests, were also confirmed using PCR.

Among the 862 samples, 32 Ctenopharyngodon idella (23.7\%), 27 Rutilus kutum (21.8 \%), 24 Hypophthalmichthys molitrix (22\%), and 21 Liza auratus (17.5\%) were naturally contaminated with Listeria spp. In addition, 12 work surface (13\%), 11 workers' hands (11.5\%), and 3 containers (3.3\%), and 3 workers' knives (3.1\%) harboured Listeria spp. Several studies on the prevalence of Listeria spp. in fish, fish products and environments have been performed worldwide [39, 40]. The prevalence of Listeria spp. isolated from raw fish and fish markets in this study concurred with the earlier findings in Iran and other countries [41, 42]. However, our findings showed higher prevalence of Listeria spp. compared with the previous studies $[43,44]$.

In the present study, L. monocytogenes was isolated from 37/488 raw fish $(7.6 \%)$ and 6/374 environments of fish markets (1.6\%). Previous reports by $\mathrm{H}$ Momtaz and S Yadollahi [43] and VS Parihar, S Barbuddhe, M-L Danielsson-Tham and W Tham [42], indicated contamination of 7.7 and $9 \%$ of fish samples with the pathogen. L. monocytogenes has been isolated from fish and fish products in earlier studies in different provinces of Iran, including Khuzestan (4 \%) [41], West Azarbaijan (2.6 \%) [45], and Gilan (2.2\%) [46]. Furthermore, other reports has shown contamination of fish market environment samples with the pathogen in central part of Iran (16.5\%) and Northern Greece (5\%) [40, 47]. It is known that L. monocytogenes is ubiquitous and can be found in soil, vegetation, sewage, surface water as well as foods [11]. Hence, it is clear that a large source of the pathogen could survive inside fish and also in its surroundings.

Of the $43 \mathrm{~L}$. monocytogenes isolates from raw fish and environment of fish market samples, 31 (72.1 \%), 10 (23.3\%), and $2(4.7 \%)$ were serovar $1 / 2 \mathrm{a}, 4 \mathrm{~b}$, and $1 / 2 \mathrm{~b}$, respectively (Table 2). We found that the $1 / 2 \mathrm{a}$ was the predominant $L$. monocytogenes serovar in the samples tested in the present study. The high percentage rate of serovar $1 / 2 \mathrm{a}$ in raw fish and environment of fish markets in this study is in agreement with the previous reports from Iran, Finland and Estonia [46-49]. Serovar 4b was isolated from raw fish only. The $4 \mathrm{~b}$ was predominant serovar in fish and seafood products in Iran, China, and Israel $[43,50,51]$. On the other hand, B Siriken, ND Ayaz and I Erol [52] recently reported that serovar $1 / 2 \mathrm{~b}$ was common serovar in Turkish raw and processed seafood products. Our finding on the presence of serovar $4 \mathrm{~b}$ indicates that fish could be a potential source of human listeriosis, in the Northern region of Iran.

Table 1 Prevalence of Listeria spp. in raw fish and environmental samples

\begin{tabular}{|c|c|c|c|c|c|c|}
\hline & No. of samples & Listeria spp. & L. monocytogenes & L. innocua & L. seeligeri & L. ivanovii \\
\hline Ctenopharyngodon idella & 135 & $32(23.7 \%)$ & $9(6.7 \%)$ & $14(10.4 \%)$ & $4(3 \%)$ & $5(3.7 \%)$ \\
\hline Rutilus kutum & 124 & 27 (21.8\%) & $14(11.3 \%)$ & $10(8.1 \%)$ & $1(0.8 \%)$ & $2(1.6 \%)$ \\
\hline Liza auratus & 120 & $21(17.5 \%)$ & $7(5.8 \%)$ & $6(5 \%)$ & $5(4.2 \%)$ & $3(2.5 \%)$ \\
\hline Hypophthalmichthys molitrix & 109 & $24(22 \%)$ & $7(6.4 \%)$ & $4(3.7 \%)$ & $11(10.1 \%)$ & $2(1.9 \%)$ \\
\hline workers' hands & 96 & $11(11.5 \%)$ & $2(2.1 \%)$ & $5(5.2 \%)$ & $1(1 \%)$ & $3(3.1 \%)$ \\
\hline workers' knives & 96 & $3(3.1 \%)$ & $1(1 \%)$ & $2(2.1 \%)$ & 0 & 0 \\
\hline Work surface & 92 & $12(13 \%)$ & $2(2.2 \%)$ & $6(6.5 \%)$ & $2(2.2 \%)$ & $2(2.2 \%)$ \\
\hline Containers & 90 & $3(3.3 \%)$ & $1(1.1 \%)$ & 0 & 0 & $2(2.2 \%)$ \\
\hline Total & 862 & $133(15.4 \%)$ & 43 (5 \%) & $47(5.5 \%)$ & $24(2.8 \%)$ & $19(2.2 \%)$ \\
\hline
\end{tabular}


Table 2 Prevalence of L. monocytogenes serovars in raw fish and environmental samples

\begin{tabular}{llll}
\hline & \multicolumn{3}{l}{ Serovars of L. monocytogenes } \\
\cline { 2 - 4 } & $1 / 2 \mathrm{a}$ & $4 \mathrm{~b}$ & $1 / 2 \mathrm{c}$ \\
\hline Ctenopharyngodon idella & $6(60 \%)$ & $3(30 \%)$ & 0 \\
Rutilus kutum & $9(64.3 \%)$ & $4(28.6 \%)$ & $1(7.1 \%)$ \\
Liza auratus & $6(85.7 \%)$ & $1(14.3 \%)$ & 0 \\
Hypophthalmichthys molitrix & $4(57.1 \%)$ & $2(28.6 \%)$ & $1(7.1 \%)$ \\
Workers' hands & $2(100 \%)$ & 0 & 0 \\
Workers' knives & $1(100 \%)$ & 0 & 0 \\
Work surface & $2(100 \%)$ & 0 & 0 \\
Containers & $1(100 \%)$ & 0 & 0 \\
Total & $31(72.1 \%)$ & $10(23.3 \%)$ & $2(4.7 \%)$ \\
\hline
\end{tabular}

All 43 isolates of L. monocytogenes were tested for the presence/absence of virulence genes $i n l A, i n l B$, inlC, and inlJ. Although, inlA, inlB, and $i n l C$ genes were observed in all of the L. monocytogenes, inlJ gene was detected in $42 / 43(97.7 \%)$ of the L. monocytogenes isolates. The surface-associated internalin is alleged to play a role in the pathogenesis of listeriosis [53]. This is the first study, to the best of our knowledge, to examine L. monocytogenes isolates from raw fish and environment of fish markets for the presence of four main internalin genes $(i n l A, i n l B, i n l C$, and inlJ). Similar results were obtained in the previous studies, where the tested internalin genes were present in almost all of the examined $L$. monocytogenes isolates from animals [17], human listeriosis [54], different kinds of foods $[15,18,24]$ and environmental samples [55].

Although, the $\operatorname{act} A, h l y A$, and iap genes were detected in all of the L. monocytogenes isolates, plcA and prfA genes were observed in 41 (95.3\%) and 42 (97.7\%) of the isolates, respectively. The prevalence rate of these five virulence genes in this study is in concurrence with the earlier studies in Iran [43] and India [56] where the act $A, h l y A$, iap, plcA, and prfA genes were observed in all the $L$. monocytogenes isolates recovered from seafood samples. The presence of nine virulence-associated genes in almost all of the L. monocytogenes isolates suggests that these isolates could be potentially virulent.

In total, 53 and 57 Listeria spp. isolates (39.8 and $42.9 \%)$ were resistant to one and two antibiotics, respectively (Table 3 ). In addition, nine isolates of Listeria spp. (6.8 \%) were multi-drug resistant. The most frequent antibiotic-resistance was resistance to tetracycline (23.3\%), followed by penicillin G, cephalothin (each $16.5 \%)$, streptomycin (15.8\%), florfenicol (15\%), erythromycin (14.3\%), ampicillin (12\%), trimethoprimsulfamethoxazole (12.5\%), ceftazidime (8.3\%), vancomycin (6\%), rifampicin (3.8\%), chloramphenicol (1.5\%),

Table 3 Resistance profiles of Listeria spp. isolated from raw fish and environmental samples

\begin{tabular}{|c|c|c|c|c|c|}
\hline & Listeria spp. $(n=133)$ & L. monocytogenes $(n=43)$ & L. innocua $(n=47)$ & L. seeligeri $(n=24)$ & L. ivanovii $(n=19)$ \\
\hline Ampicillin & $16(12 \%)$ & $9(20.9 \%)$ & $5(10.6 \%)$ & $2(8.3 \%)$ & 0 \\
\hline Chloramphenicol & $2(1.5 \%)$ & $1(2.3 \%)$ & $1(2.1 \%)$ & 0 & 0 \\
\hline Cefotaxime & 0 & 0 & 0 & 0 & 0 \\
\hline Ceftazidime & $11(8.3 \%)$ & $6(14 \%)$ & $4(8.5 \%)$ & 0 & $1(5.3 \%)$ \\
\hline Cefuroxime & $1(1.2 \%)$ & 0 & $1(3.6 \%)$ & 0 & 0 \\
\hline Cephalothin & $22(16.5 \%)$ & $7(16.3 \%)$ & 11 (23.4 \%) & $3(12.5 \%)$ & $1(5.3 \%)$ \\
\hline Erythromycin & $19(14.3 \%)$ & $6(14 \%)$ & $9(19.1 \%)$ & $3(12.5 \%)$ & $1(5.3 \%)$ \\
\hline Florfenicol & $20(15 \%)$ & $6(14 \%)$ & $11(23.4 \%)$ & $2(8.3 \%)$ & $1(5.3 \%)$ \\
\hline Gentamycin & 0 & 0 & 0 & 0 & 0 \\
\hline Kanamycin & 0 & 0 & 0 & 0 & 0 \\
\hline Pefloxacin & 0 & 0 & 0 & 0 & 0 \\
\hline Penicillin G & $22(16.5 \%)$ & $7(16.3 \%)$ & $9(19.1 \%)$ & $2(8.3 \%)$ & $4(21.1 \%)$ \\
\hline Rifampicin & $5(3.8 \%)$ & $1(2.3 \%)$ & $2(4.3 \%)$ & $2(8.3 \%)$ & 0 \\
\hline Streptomycin & $21(15.8 \%)$ & $7(16.3 \%)$ & $8(17 \%)$ & $3(12.5 \%)$ & $3(15.8 \%)$ \\
\hline Tetracycline & $31(23.3 \%)$ & $12(27.9 \%)$ & $11(23.4 \%)$ & $5(20.8 \%)$ & $3(15.8 \%)$ \\
\hline Trimethoprim-sulfamethoxazole & $14(10.5 \%)$ & $5(11.6 \%)$ & $5(10.6 \%)$ & $3(12.5 \%)$ & $1(5.3 \%)$ \\
\hline Vancomycin & $8(6 \%)$ & $3(7 \%)$ & $4(8.5 \%)$ & 1 (4.2\%) & 0 \\
\hline Resistant to 1 antibiotic & $53(39.8 \%)$ & 15 (34.9\%) & $14(29.8 \%)$ & $10(41.7 \%)$ & $14(73.7 \%)$ \\
\hline Resistant to 2 antibiotics & $57(42.9 \%)$ & $20(46.5 \%)$ & $27(57.4 \%)$ & $8(33.3 \%)$ & $2(10.5 \%)$ \\
\hline Resistant to $>2$ antibiotics & $9(6.8 \%)$ & $6(14 \%)$ & $3(6.4 \%)$ & 0 & 0 \\
\hline
\end{tabular}


and cefuroxime (1.2\%). Out of $43 \mathrm{~L}$. monocytogenes isolates, 15 (34.9\%), 20 (46.5\%) and 6 (6.4\%) were resistant to one, two and more than two antibiotics. The L. monocytogenes isolates indicated high resistance to tetracycline (27.9\%), ampicillin (20.9\%), cephalothin, penicillin G, and streptomycin (each $16.3 \%$ ). All of the Listeria spp. isolates were sensitive to cefotaxime, gentamicin, kanamycin, and pefloxacin.

The 43 L. monocytogenes were examined for the presence of resistance genes. Six of $43 \mathrm{~L}$. monocytogenes isolates $(14 \%)$ harbored more than one antimicrobial resistance gene. Among the evaluated serovars of L. monocytogenes isolates, a higher prevalence of antimicrobial resistance genes was detected in serovar $1 / 2 \mathrm{a}$ (81.5\%), followed by serovar $4 \mathrm{~b}$ (18.5\%). However, the resistance genes were not found in serovar $1 / 2 \mathrm{c}$ isolates.

For tetracycline resistance, the tet $M$ and tet $A$ genes were present in 91.7 and $83.3 \%$ of the tetracyclineresistant isolates, respectively and $71.4 \%$ of the penicillin-resistant isolates harboured penA gene. Out of 7 streptomycin-resistant isolates, 42.9 and $14.3 \%$ isolates contained $\operatorname{str} A$, and $\operatorname{str} B$, respectively. Furthermore, the $a m p C$ and $v a n A$ resistance genes were found in 66.7 and $33.3 \%$ of the ampicillin- and vancomycin-resistant isolates, respectively. However, the tet $B$, tet $C$, tet $L$, tet $S$ folR, $c m l A$, and $v a n B$ were not detected in the examined L. monocytogenes isolates from raw fish and open-air fish market environments. The prevalence rate of the tet $M$, tet $A$, pen $A$ and strA genes in the present study is in agreement with earlier investigations, in which a high frequency of these resistance genes in L. monocytogenes isolates was reported by $\mathrm{C}$ Poyart-Salmeron, $\mathrm{P}$ TrieuCuot, C Carlier, A MacGowan, J McLauchlin and P Courvalin [57], and V Srinivasan, H Nam, L Nguyen, B Tamilselvam, S Murinda and S Oliver [29].

In the current study, the phenotypic resistance profiles of the L. monocytogenes isolates were not confirmed by detection of resistance genes. For instance, 2 of 6 vancomycin-resistant isolates which showed phenotypic resistance to vancomycin, harbored vanA gene and none of them contained vanB. Likewise, out of 43 L. monocytogenes isolates, 7 (16.3\%) were phenotypically resistant to penicillin $\mathrm{G}$, however, only 6 of the isolates (11.6\%) carried penA resistance gene. The same results were reported in earlier studies [29]. This inconsistency suggests that mutation in ribosomal protein gene or decreased outer membrane permeability can contribute to antimicrobial resistance phenotypes $[58,59]$.

A high resistance of $L$. monocytogenes to tetracycline and penicillin $G$ was observed in the present study. Our findings were in agreement with a previous investigation, in which a high resistance of $L$. monocytogenes to tetracycline and penicillin $G$ was also reported by AA Fallah, SS Saei-Dehkordi and M Mahzounieh [47], and
O Rodas-Suárez, J Flores-Pedroche, J Betancourt-Rule, EI Quiñones-Ramírez and C Vázquez-Salinas [39]. Tetracycline and fluoroquinolones are widely applied as growth supplement and therapeutic agents in Iranian fish farms, respectively. The presence of antibioticresistant $L$. monocytogenes as well as multi-drug resistant isolates in fish on the one hand and transmission of the pathogen through contaminated fish on the other hand, clarify major public health concerns associated with this pathogen.

\section{Conclusions}

In conclusion, recovery of potentially pathogenic L. monocytogenes from raw fish and environment of open-air fish market samples evidences the zoonotic potential of listeriosis. Hence, further surveillance of the prevalence of L. monocytogenes and also of emerging antibiotic resistance is required to enable the recognition of the contaminated foods, as well as ensure the effective antibiotic treatment.

\section{Competing interests}

The authors declare that they have no competing interests.

\section{Authors' contributions}

$B R$ designed the study. HJ, MP and BR were responsible for isolation, antimicrobial susceptibility test, serotyping, virulotyping of the strains and drafted the manuscript. CYL, WFW, SI, and AA contributed ideas and edited the manuscript. All authors read, commented on, and approved the final manuscript.

\section{Acknowledgment}

This study was supported by funding from Islamic Azad University-Karaj Branch and a research grant from University of Malaya (RG525-13HTM).

\section{Author details}

${ }^{1}$ Biohealth Science Program, Institute of Biological Science, Faculty of Science, University of Malaya, 50603 Kuala Lumpur, Malaysia. ${ }^{2}$ Department of Pharmacology, Faculty of Medicine, University of Malaya, 50603 Kuala Lumpur, Malaysia. ${ }^{3}$ Department of Medical Microbiology, Faculty of Medicine, University of Malaya, 50603 Kuala Lumpur, Malaysia. ${ }^{4}$ Department of Food Hygiene and Quality Control, Islamic Azad University-Karaj Branch, Karaj 31485-313, Iran. ${ }^{5}$ Centre de Recherche en Reproduction Animale, Université de Montréal, C.P. 5000 St-Hyacinthe, QC, Canada.

Received: 11 August 2014 Accepted: 3 July 2015

Published online: 25 July 2015

\section{References}

1. Cocolin L, Stella S, Nappi R, Bozzetta E, Cantoni C, Comi G. Analysis of PCR-based methods for characterization of Listeria monocytogenes strains isolated from different sources. Int J Food Microbiol. 2005;103:167-78.

2. Liu D. Epidemiology. In: Liu D, editor. Handbook of Listeria monocytogenes. New York: CRC Press; 2008. p. 27-30.

3. Mead PS, Slutsker L, Dietz V, McCaig LF, Bresee JS, Shapiro C, et al. Food-related illness and death in the United States. Emerg Infect Dis. 1999:5:607.

4. FAO. Fisheries report No. 604. In: Expert consultation on the trade impact of Listeria in fish products. Amherst, MA, USA: FAO; 1999.

5. Tham W, Ericsson H, Loncarevic S, Unnerstad H, Danielsson-Tham M-L. Lessons from an outbreak of listeriosis related to vacuum-packed gravad and cold-smoked fish. Int J Food Microbiol. 2000;62(3):173-5.

6. Kasper S, Huhulescu S, Auer B, Heller I, Karner F, Würzner R, et al. Epidemiology of listeriosis in Austria. Wien Klin Wochenschr. 2009;121:113-9. 
7. Kathariou S. Listeria monocytogenes virulence and pathogenicity, a food safety perspective. J Food Prot. 2002;65:1811-29.

8. Swaminathan B, Gerner-Smidt P. The epidemiology of human listeriosis. Microbes Infect. 2007;9:1236-43.

9. Zhang Y, Yeh E, Hall G, Cripe J, Bhagwat AA, Meng J. Characterization of Listeria monocytogenes isolated from retail foods. Int J Food Microbiol. 2007;113:47-53.

10. Cartwright EJ, Jackson KA, Johnson SD, Graves LM, Mahon BE, Silk BJ. Listeriosis outbreaks and associated food vehicles, United States, 1998-2008. Emerg Infect Dis. 2013;19:1-9.

11. Farber J, Peterkin P. Listeria monocytogenes, a food-borne pathogen. Microbiol Rev. 1991;55:476-511.

12. Orsi R, Ripoll D, Yeung M, Nightingale K, Wiedmann M. Recombination and positive selection contribute to evolution of Listeria monocytogenes in/A. Microbiology. 2007;153:2666-78.

13. Liu D, Lawrence ML, Austin FW, Ainsworth AJ. A multiplex PCR for species-and virulence-specific determination of Listeria monocytogenes. Microbiol Methods. 2007;71:133-40.

14. Vázquez-Boland JA, Kuhn M, Berche P, Chakraborty T, Domínguez-Bernal G, Goebel W, et al. Listeria pathogenesis and molecular virulence determinants. Clin Microbiol Rev. 2001;14:584-640.

15. Sant'Ana AS, Igarashi MC, Landgraf M, Destro MT, Franco BD. Prevalence, populations and pheno-and genotypic characteristics of Listeria monocytogenes isolated from ready-to-eat vegetables marketed in São Paulo, Brazil. Int J Food Microbiol. 2012;155:1-9.

16. Schwartz T, Kohnen W, Jansen B, Obst U. Detection of antibiotic-resistant bacteria and their resistance genes in wastewater, surface water, and drinking water biofilms. FEMS Microbiol Ecol. 2003;43:325-35.

17. Jamali H, Radmehr B. Frequency, virulence genes and antimicrobial resistance of Listeria spp. isolated from bovine clinical mastitis. Vet J. 2013;198:541-2.

18. Jamali H, Radmehr B, Thong KL. Prevalence, characterisation, and antimicrobial resistance of Listeria species and Listeria monocytogenes isolates from raw milk in farm bulk tanks. Food Control. 2013:34:121-5.

19. Marian M, Sharifah Aminah S, Zuraini M, Son R, Maimunah M, Lee $H$, et al. MPN-PCR detection and antimicrobial resistance of Listeria monocytogenes isolated from raw and ready-to-eat foods in Malaysia. Food Control. 2012;28:309-14.

20. Safdar A, Armstrong D. Antimicrobial activities against 84 Listeria monocytogenes isolates from patients with systemic listeriosis at a comprehensive cancer center (1955-1997). J Clin Microbiol. 2003;41:483-5.

21. Harakeh S, Saleh I, Zouhairi O, Baydoun E, Barbour E, Alwan N. Antimicrobial resistance of Listeria monocytogenes isolated from dairy-based food products. Sci Total Environ. 2009:407:4022-7.

22. ISO 11290-1. Microbiology of food and animal feeding stuffs - horizontal method for the detection and enumeration of Listeria monocytogenes - Part 1 : detection method. Geneva: International Organization for Standardization; 1996.

23. Aznar R, Alarcón B. PCR detection of Listeria monocytogenes: a study of multiple factors affecting sensitivity. J Appl Microbiol. 2003;95(5):958-66.

24. Jamali H, Thong KL. Genotypic characterization and antimicrobial resistance of Listeria monocytogenes from ready-to-eat foods. Food Control. 2014;44:1-6.

25. Kalorey D, Kurkure N, Warke S, Rawool D, Malik S, Barbuddhe S. Isolation of pathogenic Listeria monocytogenes in faeces of wild animals in captivity. Comp Immunol Microbiol Infect Dis. 2006;29:295-300.

26. CLSI. Methods for antimicrobial dilution and disk susceptibility testing of infrequently isolated or fastidious bacteria; approved guideline (M45-A2). Wayne, PA: Clinical and Laboratory Standards Institute; 2010.

27. Conter M, Paludi D, Zanardi E, Ghidini S, Vergara A, lanieri A Characterization of antimicrobial resistance of foodborne Listeria monocytogenes. Int J Food Microbiol. 2009;128(3):497-500.

28. Li Q, Sherwood J, Logue C. Antimicrobial resistance of Listeria spp. recovered from processed bison. Lett Appl Microbiol. 2007;44(1):86-91.

29. Srinivasan V, Nam H, Nguyen L, Tamilselvam B, Murinda S, Oliver S. Prevalence of antimicrobial resistance genes in Listeria monocytogenes isolated from dairy farms. Foodbourne Pathog Dis. 2005;2:201-11.

30. Gevers D, Danielsen M, Huys G, Swings J. Molecular characterization of tet( $M)$ genes in Lactobacillus isolates from different types of fermented dry sausage. Appl Environ Microbiol. 2003;69(2):1270-5.

31. Clermont D, Chesneau O, De Cespédès G, Horaud T. New tetracycline resistance determinants coding for ribosomal protection in streptococci and nucleotide sequence of tet $(T)$ isolated from Streptococcus pyogenes A498. Antimicrob Agents Chemother. 1997;41(1):112-6.

32. Charpentier E, Gerbaud G, Courvalin P. Characterization of a new class of tetracycline-resistance gene tet(S) in Listeria monocytogenes BM4210. Gene. 1993;131(1):27-34

33. Guillaume G, Verbrugge D, Chasseur-Libotte ML, Moens W, Collard JM. PCR typing of tetracycline resistance determinants (Tet A-E) in Salmonella enterica serotype Hadar and in the microbial community of activated sludges from hospital and urban wastewater treatment facilities in Belgium. FEMS Microbiol Ecol. 2000;32:77-85.

34. Lanz $R$, Kuhnert $P$, Boerlin P. Antimicrobial resistance and resistance gene determinants in clinical Escherichia coli from different animal species in Switzerland. Vet Microbiol. 2003:91:73-84.

35. Okamoto K, Gotoh N, Nishino T. Extrusion of penem antibiotics by multicomponent efflux systems MexAB-OprM, MexCD-OprJ, and MexXY-OprM of Pseudomonas aeruginosa. Antimicrob Agents Chemother. 2002:46:2696-9.

36. Sutcliffe J, Tait-Kamradt A, Wondrack L. Streptococcus pneumoniae and Streptococcus pyogenes resistant to macrolides but sensitive to clindamycin: a common resistance pattern mediated by an efflux system. Antimicrob Agents Chemother. 1996:40:1817-24.

37. Keyes K, Hudson C, Maurer JJ, Thayer S, White DG, Lee MD. Detection of florfenicol resistance genes in Escherichia coli isolated from sick chickens. Antimicrob Agents Chemother. 2000;44:421-4.

38. Gebreyes WA, Altier C. Molecular characterization of multidrug-resistant Salmonella enterica subsp. enterica serovar Typhimurium isolates from swine. J Clin Microbiol. 2002:40:2813-22.

39. Rodas-Suárez O, Flores-Pedroche J, Betancourt-Rule J, Quiñones-Ramírez El, Vázquez-Salinas C. Occurrence and antibiotic sensitivity of Listeria monocytogenes strains isolated from oysters, fish, and estuarine water. Appl Environ Microbiol. 2006;72:7410-2.

40. Soultos N, Abrahim A, Papageorgiou K, Steris V. Incidence of Listeria spp. in fish and environment of fish markets in Northern Greece. Food Control. 2007;18:554-7.

41. Maktabi S, Fazlara A, Ebrahimian S. Incidence of Listeria species in farmed tropical fish in Khuzestan, Iran. World J Fish Marine Sci. 2011;3:206-9.

42. Parihar VS, Barbuddhe S, Danielsson-Tham M-L, Tham W. Isolation and characterization of Listeria species from tropical seafoods. Food Control. 2008;19:566-9.

43. Momtaz H, Yadollahi S. Molecular characterization of Listeria monocytogenes isolated from fresh seafood samples in Iran. Diagn Pathol. 2013;8:149.

44. Rahimi E, Shakerian A, Raissy M. Prevalence of Listeria species in fresh and frozen fish and shrimp in Iran. Ann Microbiol. 2012:62:37-40.

45. Modaresi R, Mardani K, Tukmechi A, Ownagh A. Prevalence of Listeria spp. in fish obtained from Urmia fish markets. Afr J Microbiol Res. 2011;5:5398-401.

46. Basti AA, Misaghi A, Salehi TZ, Kamkar A. Bacterial pathogens in fresh, smoked and salted Iranian fish. Food Control. 2006:17:183-8.

47. Fallah AA, Saei-Dehkordi SS, Mahzounieh M. Occurrence and antibiotic resistance profiles of Listeria monocytogenes isolated from seafood products and market and processing environments in Iran. Food Control. 2013:34:630-6.

48. Johansson T, Rantala L, Palmu L, Honkanen-Buzalski T. Occurrence and typing of Listeria monocytogenes strains in retail vacuum-packed fish products and in a production plant. Int J Food Microbiol. 1999;47:111-9.

49. Kramarenko T, Roasto M, Meremäe K, Kuningas M, Põltsama P, Elias T. Listeria monocytogenes prevalence and serotype diversity in various foods. Food Control. 2013:30:24-9.

50. Vasilev $V$, Japheth $R$, Breuer $R$, Andorn $N$, Ben Abraham $R$, Yoni $Y$, et al. A survey of Listeria monocytogenes strains, isolated from ready-to-eat foods in Israel over a period of 10 years, 1998-2007. Food Control. 2010;21:1179-81.

51. Wang X-M, Lü X-F, Yin L, Liu H-F, Zhang W-J, Si W, et al. Occurrence and antimicrobial susceptibility of Listeria monocytogenes isolates from retail raw foods. Food Control. 2013;32:153-8.

52. Siriken B, Ayaz ND, Erol I. Prevalence and serotype distribution of Listeria monocytogenes in salted anchovy, raw anchovy, and raw mussel using IMS-based cultivation technique and PCR. J Aquat Food Product Technol. 2013;22:77-82.

53. McGann P, Raengpradub S, Ivanek R, Wiedmann M, Boor KJ. Differential regulation of Listeria monocytogenes internalin and internalin-like genes by ob and PrfA as revealed by subgenomic microarray analyses. Foodborne Pathog Dis. 2008;5:417-35. 
54. Mammina C, Aleo A, Romani C, Pellissier N, Nicoletti P, Pecile P, et al. Characterization of Listeria monocytogenes isolates from human listeriosis cases in Italy. J Clin Microbiol. 2009;47(9):2925-30.

55. GelbíčoVá T, KaRpíšKoVá R. Outdoor environment as a source of Listeria monocytogenes in food chain. Czech Journal of Food Science. 2012;30:83-8.

56. Das S, Lalitha KV, Thampuran N, Surendran PK. Isolation and characterization of Listeria monocytogenes from tropical seafood of Kerala, India. Ann Microbiol. 2013:63:1093-8.

57. Poyart-Salmeron C, Trieu-Cuot P, Carlier C, MacGowan A, McLauchlin J, Courvalin P. Genetic basis of tetracycline resistance in clinical isolates of Listeria monocytogenes. Antimicrob Agents Chemother. 1992;36(2):463-6.

58. Yan W, Taylor D. Characterization of erythromycin resistance in Campylobacter jejuni and Campylobacter coli. Antimicrob Agents Chemother. 1991;35:1989-96.

59. Farmer S, Li Z, Hancock RE. Influence of outer membrane mutations on susceptibility of Escherichia coli to the dibasic macrolide azithromycin. J Antimicrob Chemother. 1992;29:27-33.

\section{Submit your next manuscript to BioMed Central and take full advantage of:}

- Convenient online submission

- Thorough peer review

- No space constraints or color figure charges

- Immediate publication on acceptance

- Inclusion in PubMed, CAS, Scopus and Google Scholar

- Research which is freely available for redistribution 